\title{
The Effect of Watering on a Prairie Vole Population
}

\author{
Eisa Mi. ABDELlatif,${ }^{1}$ Kenneth B. ARMITAGE, Michael S. GAINES \\ \& Michael L. JOHNSON
}

\begin{abstract}
Abdellatif E. M., Armitage K. B., Gaines M. S. \& Johnson M. L.: The effect of watering on a prairie vole population. Acta theriol., 27, 18: 243-255 [With 4 Tables \& 3 Figs.]

This study tested the null hypothesis that shortage of neither water per se nor water as a stimulator of vegetative growth cause the depression of reproduction in Microtus ochrogaster populations during summer. Three 0.81 ha enclosures were used; one was watered, one was provided with water bottles, the third served as a control. About 200 voles were live-trapped during May 21 through October 16, 1979. Starting the last day of September, captured animals were removed, autopsied, and examined for physiological response to the dry period of September. The watered enclosure supported significantly heavier voles $(p<0.005)$ and more breeding females $(p<0.025)$ than either of the other populations. Moreover, the control population lost a significantly higher proportion of embryos than the watered population $(p<0.005)$. The enclosure provided with water bottles failed to support significantly heavier voles or significantly more breeding females than did the control. The results of the study suggest that depression of summer reproduction was, at least partially, attributable to shortage of water as a stimulator of vegetative growth. A graphical model, illustrating the proximate effects of watering, is presented.

[Department of Systematics and Ecology, The University of Kansas, Lawrence, Kansas USA 66045]
\end{abstract}

\section{INTRODUCTION}

Successful reproduction is the central strategy in the life history of living organisms (Stearns, 1976). Iteroparous organisms, particularly homeotherms, have high energetic demands for maintenance which must be satisfied prior to reproduction. Consequently, many factors potentially limit their reproductive activity. Cycles in the densities of microtine rodents were attributed to temporal variation in their reproductive rate (Hamilton, 1941). Subsequent studies on a number of microtine species failed to support this suggestion (Rose \& Gaines, 1978); however, reproduction varied seasonally.

Reproductive decline during the summer was attributed to shortage

${ }^{1}$ Permanent address: Zology Department, University of Khartoum, Khartoum, Sudan. 
of food (Batzli \& Pitelka, 1971). Breeding activity and population density of the prairie vole, Microtus ochrogaster, sharply declined during the summer in eastern Kansas (Jameson, 1947; Martin, 1956 ; Fitch, 1957), in Indiana (Corthrum, 1967), and in Illinois (Cole \& Batzli, 1979). Depression of reproduction occurred in four successive summers near Lawrence, Kansas (Gaines \& Rose, 1976). This decline was more closely correlated with season than density and was attributed to the evolutionary history of this species (Rose \& Gaines, 1978).

The correlation of breeding depression with summer and low vegetative cover suggests shortage of water and/or food and cover (Birney et al., 1976) are factors limiting reproduction of microtines. Among three types of habitat $M$. ochrogaster had greater reproductive rate, litter size, body weight, survival rate, and fat reserves in the high food quality habitat (Cole \& Batzli, 1979). An artificial water supply stimulated the reproductive activity of a Peromyscus truei population during summer (Bradford, 1975). However, Bradford concluded that food shortage, not water stress, was the proximal factor limiting reproduction. A water-treated population of house mice, Mus musculus, had significantly higher rates of survival and recruitment; however, water and food supplement did not arrest the continuous decline of the summer population (Newsome et al., 1976). Finally among four species of small mammals, $M$. ochrogaster responded most when the habitat was modified by watering and nitrogen treatment (Grant et al., 1977). This study tested the null hypothesis that shortage of water per se or as a stimulator of vegetative growth does not affect reproduction or population growth of $M$. ochrogaster during summer.

\section{MATERIALS AND METHODS}

\section{Study Area}

This study utilized three adjacent 0.81 ha. small mammal enclosures located in the Nelson Environmental Study Area, $14 \mathrm{~km}$. northeast of Lawrence, Kansas. The enclosures were positioned to provide as much similarity among them as possible. Galvanized steel siding, $66 \mathrm{~cm}$. high, prevented both egress and ingress of voles. Each enclosure had 12 dispersal openings that were closed several days before the study began. The vegetation was dominated by Smooth Brome (Bromus inermis), Sand Dropseed (Sporobolus cryptandrus), Downy Brome (B. tectorum) and Japanese Brome (B. japonicum). Other scattered vegetation included Green Foxtail (Setaria viridis), Ragweed (Ambrosia sp.), Golden Rod (Solidago sp.), Sunflower (Helianthus sp.) and Poison Ivy (Toxicodendron radicans).

Lawrence is situated near the western edge of the eastern hardwood forest at $38^{\circ} 58^{\prime} \mathrm{N}$. latitude and $95^{\circ} 16^{\prime} \mathrm{W}$. longitude. The average annual temperature is 
$13.6^{\circ} \mathrm{C}$ with great fluctuation typical of a continental climate. The annual rainfall averages $878 \mathrm{~mm}$., of which $70 \%$ falls during the warm months, April to September. Summer precipitation varies and usually results from thunderstorm activity.

\section{Trapping Procedure}

A trapping grid, established in each enclosure, consisted of 100 trap-stations at $7.6 \mathrm{~m}$. spacing, each marked with a numbered wooden stake. A Longworth trap was provided with cotton for nesting, placed within $0.3 \mathrm{~m}$. of each stake, and covered with a wooden board. Traps were prebaited with wheat and locked open for 11 days. They were then cleaned, rebaited, and set on Sunday evenings, usually within two hours before dark. On Monday mornings, generally within an hour after sunrise, traps were checked for captured animals and then closed to prevent heat mortality in the traps. They were reset Monday evenings and checked on Tuesday mornings when the trapping period ended.

Ten pairs of randomly chosen adult and subadult voles from a laboratory colony were ear-tagged with fish fingerling tags, weighed, examined for external reproductive condition, and introduced into each of the three enclosures on May 21, 1979. Trapping followed weekly for three weeks, biweekly through September, and daily through October 16, 1979.

Upon first capture, each animal was ear-tagged, sexed, weighed, and examined for external reproductive condition. Data recorded for each animal were: (a) identification number; (b) location of capture; (c) body weight to the nearest gram; (d) sex; (e) testes position (scrotal or abdominal) for males; (f) vaginal opening (perforate or nonperforate), nipple size (small, medium, or large), and condition of the pubic symphysis (closed, slightly open, or open) for females; (g) females with bulging abdomen were recorded as being pregnant.

Occasional snap-trapping around the three enclosures revealed no signs of emigration.

Demographic data were analyzed by the aid of a computer package (Krebs, 1967).

\section{Treatment}

One enclosure (W) was watered by eight sprinklers from two water outlets every week, unless the precipitation amounted to more than $50 \mathrm{~mm}$. In a second enclosure (B), a water bottle tied to a stake, at each trapping station, provided drinking water without interfering with the vegetative growth. The bottles, sealed with petroleum jelly to minimize evaporation, were checked weekly and were rarely empty. The third enclosure $(C)$ served as a control. In the subsequent text the abbreviations $W, B$, and $C$ will be used to stand for watered, water bottles, and control, respectively. Ambient temperature and relative humidty were recorded by a hygrothermograph and precipitation was recorded weekly from a rain gauge, both placed at the center of each of the treatment enclosures ( $W$ and $B$ ). Soil moisture, read approximately biweekly, was measured by three gypsum blocks buried at depths of $10.2,20.3$, and $30.5 \mathrm{~cm}$., respectively, in each enclosure.

\section{Autopsy}

Removal trapping began on the last day of September and continued daily through October 16, 1979. Captured animals were examined as described above 
and taken to the laboratory where they were sacrificed and frozen. The voles were autopsied to examine their physiological response to the protracted period of drought that occurred during September.

After thawing, each vole was dissected and the following data were recorded for females: uterine width of nonpregnant females, uterus weight in grams, including embryos, if any, number of healthy and resorbing embryos in each uterine horn, average length of healthy and resorbing embryos in mm, number of placental scars in each uterine horn, number and average diameter $(\mathrm{mm})$ of corpora lutea in each ovary, and for males: testes position (scrotal or abdominal), testes size (length $\times$ width in $\mathrm{mm}^{2}$ ), weight of paired testes in grams, length of the seminal vesicle to the nearest $\mathrm{mm}$, condition of the epididymal tubules (convoluted, slightly convoluted or not convoluted).

Unless specified, all statistical tests used for analysis of demographic and autopsy data were obtained from Sokal \& Rohlf (1969).

\section{RESULTS}

\section{Weather Information}

From July 25 through October 3,1979 , the mean daily minimum and maximum temperatures were $15.9 \pm 0.54^{\circ} \mathrm{C}$ (range $=5-23$ ) and 28.6 \pm $0.53^{\circ} \mathrm{C}$ (range $=17-34$ ), respectively (Abdellatif, 1980). Relative humidity was high most of the time with the minimum and maximum values averaging $66 \%$ and $99 \%$, respectively. The weekly rainfall averaged $18.8 \pm 8.0 \mathrm{~mm}$ with a range of 0.0 to $71.1 \mathrm{~mm}$. The summer of 1979 was wetter than normal and the only protracted drought occurred from September 5 through the end of the study. Soil moisture was high in all enclosures until mid-September when it declined abruptly in enclosures $B$ and $C$ (Abdellatif, 1980). There was a significant difference in soil moisture among the three enclosures over the three depths $(p<0.005$, 3 -way anova). The watered enclosure $(W)$ was significantly moister than enclosure $B$ at $10.2 \mathrm{~cm}(p<0.05)$, and than both enclosures $B$ and $C$ at $20.3 \mathrm{~cm}(p<0.05$, SNK Multiple Comparison). All other comparisons revealed no significant difference $(p>0.05)$.

\section{Demography}

The number of captured males and females per trapping session did not differ significantly within any of the populations $(p>0.10$ for each population; Wilcoxon's signed rank rest). Hence, data were pooled for the two sexes. The number of captures was not significantly different among the three populations ( $p>0.90$; Kruskal-Wallis test). However, the control population was initially larger and declined sharply relative to the other two populations (Fig. 1). All populations declined throughout 
the summer. Because numbers were low in late July-early August, 3 males and 2 females from the laboratory population were introduced into each field population on August 14, 1979. Body weights of these voles did not differ significantly. Although the number of captures increased in the next trapping period, the vole populations continued to decline.

The initial body weights of the ten pairs of animals introduced into each enclosure were not significantly different among the three populations ( $p>0.10$ for each sex; Kruskal-Wallis test). Body weight of

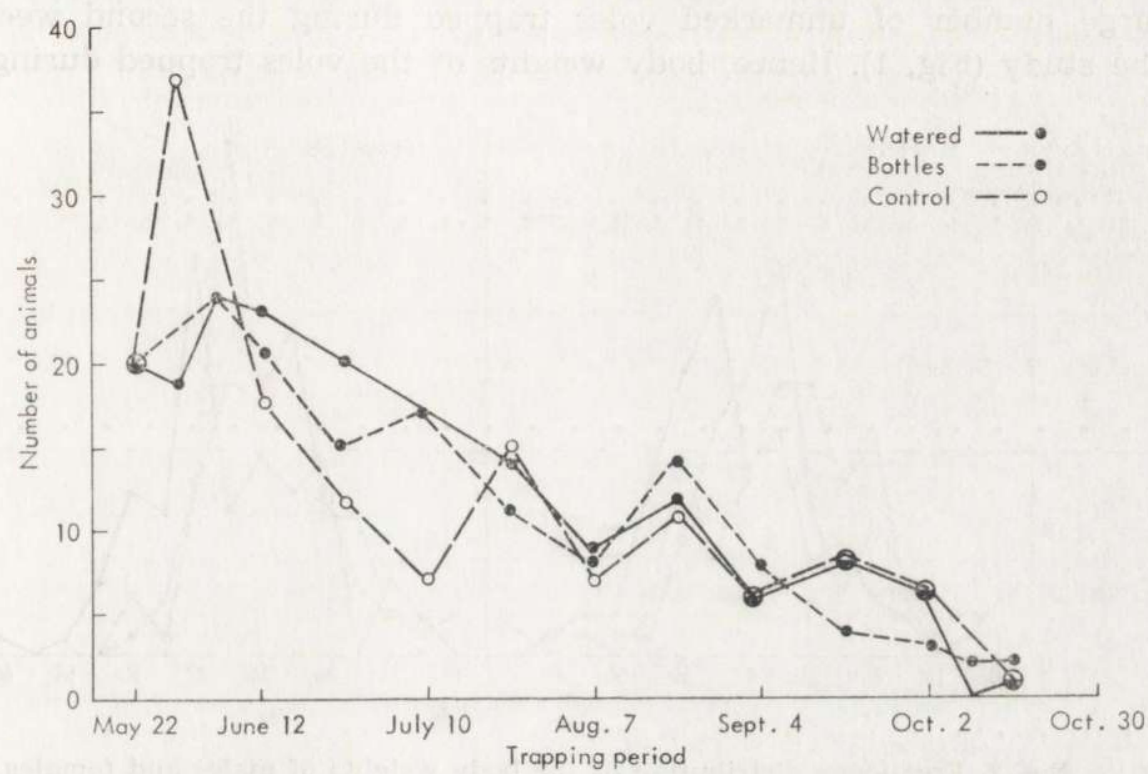

Fig. 1. Number of animals captured per trapping period. (Each point represents the total number captured by the end of the trapping period).

individual voles was counted every trapping period they were captured. Males were significantly heavier than females in both watered and control populations $(p<0.005$ and $p<0.05$, respectively; $t$-test). Hence, data for males and females were analyzed separately.

Body weights were assigned to weight classes with intervals of 4 grams each (Abdellatif, 1980). The frequency distribution of body weight classes was calculated and plotted for each sex (Fig. 2). The curves of population $W$ indicate high frequency of heavy body weights for both males and females. On the other hand, the distribution of weights of males of population $B$ and of females of population $C$ was skewed to the left (Fig. 2).

Males of the watered population were significantly heavier than those 6-Acta Theriologica 
of both other populations $(p<0.005)$; but unexpectedly, the males of population $C$ were significantly heavier than those of population $B$ $(p<0.005$; distribution-free multiple comparison, Hollander and Wolfe, 1973). The watered enclosure supported significantly heavier females than both other enclosures $(p<0.005)$, while population $B$ had significantly heavier females than population $C(p<0.01)$.

However, there were immigrant voles in the enclosures before the introduction of laboratory animals. The control enclosure had received more immigrants than either of the other two enclosures, indicated by the large number of unmarked voles trapped during the second week of the study (Fig. 1). Hence, body weights of the voles trapped during the

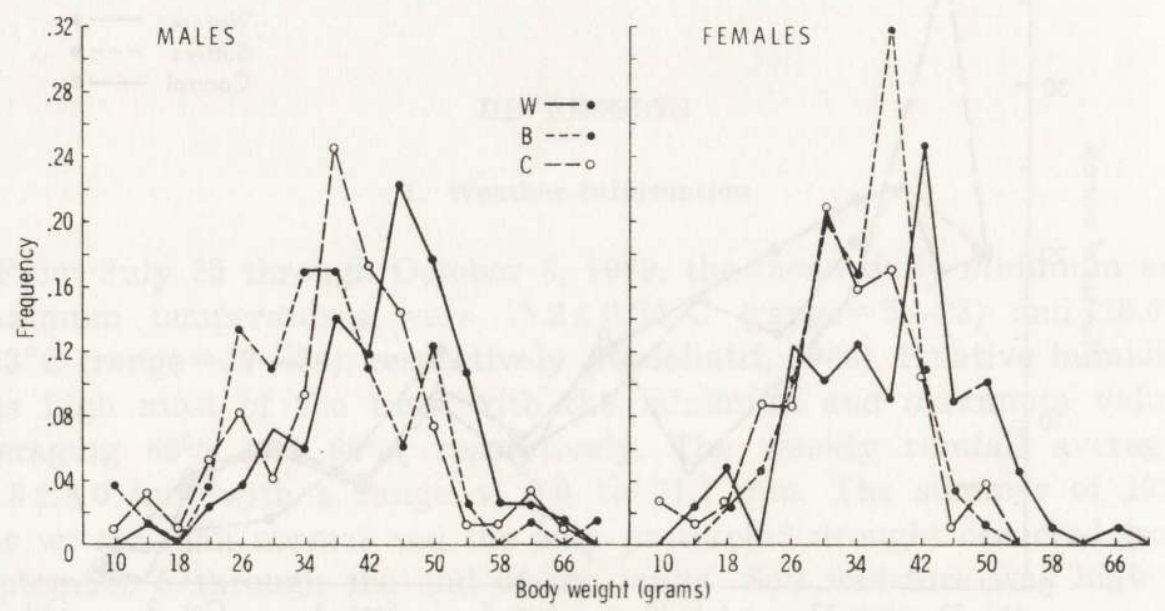

Fig. 2. Frequency distribution of the body weights of males and females.

first two weeks (May 22 and 29, 1979) were lumped and analyzed for differences among the three populations.

Body weights of females did not differ significantly among the three populations $(p>0.10)$; body weights of males were significantly different $(p<0.01$, Kruskal-Wallis test). Population $W$ had significantly heavier males than population $B(p<0.05)$ and population $C(p<0.01)$, while populations $B$ and $C$ did not differ significantly $(p>0.20$, Mann-Whitney test).

Minimum survival rate $(S)$ was calculated for periods of two weeks as follows (Krebs, 1967) :

$$
S=\exp \left(\frac{1 \mathrm{n} N_{2} / N_{1}}{t}\right)
$$

where, $N_{1}=$ number of animals captured at time $1, N_{2}=$ number of animals captured at time 2, $t=$ interval between time 1 and 2 . 
In the statistical analysis, age groups were considered separately to avoid interaction effect. Survival rate did not differ significantly among the three populations $(p>0.50$ for males and $0.05<p<0.10$ for females; Friedman's randomized block test). Therefore, there is no reason to reject the null hypothesis that watering did not affect survival of the voles.

Simple linear regression of instantaneous relative growth rates $(g)$ on mean body weights $(w)$ were calculated for each four week period (Table 1) where :

$$
\begin{array}{r}
g=\frac{\ln \left(W_{2} / W_{1}\right)}{t} \\
w=\frac{W_{1}+W_{2}}{2}
\end{array}
$$

$W_{1}=$ weight at time $1, W_{2}=$ weight at time $2, t=$ interval between time 1 and time 2 .

Table 1

Regression coefficients of instantaneous relative growth rates on mean body weights per four weeks. $W:=$ watered enclosure; $B=$ enclosure provided with water bottles; $C=$ control enclosure.

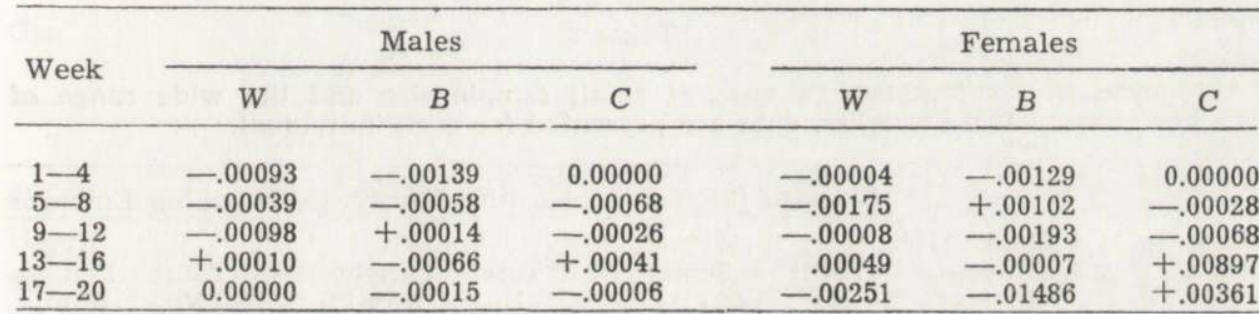

The regression coefficients of instantaneous relative growth rates on mean body weights did not differ significantly among the three populations ( $p>0.50$ for males and $p>0.10$ for females; Friedman's randomized block test). Hence, there is no reason to assume that water treatment affected the growth rates of the voles.

Each trapping period the voles were classified individually as either breeding or nonbreeding. Breeding males were those having scrotal testes. Breeding females were those having perforate vaginal opening, medium or large nipples and/or slightly open or open pubic symphysis. The classification of voles into adult, subadult and juvenile cohorts was not related to the reproductive condition, but to body weights.

The number of breeding subadult males and females and adult males did not differ significantly among the three populations $(p>0.05, p>0.10$ and $p>0.10$, respectively; $G$-test). However, the number of breeding 
adult females and total number of breeding females differed significantly among the three populations $(p<0.005 ; G$-test $)$. Fewer females in the control population bred (Table 2). The number of breeding females was

Table 2

Number of breeding (b) and nonbreeding (n-b) voles according to sex and age groups. $W=$ watered enclosure; $B=$ enclosure with water bottles; $C=$ control.

\begin{tabular}{|c|c|c|c|c|c|c|}
\hline & \multicolumn{2}{|c|}{$W$} & \multicolumn{2}{|c|}{$B$} & \multicolumn{2}{|c|}{ C } \\
\hline & $\mathrm{b}$ & $n-b$ & $\mathrm{~b}$ & $n-b$ & b & $\mathrm{n}-\mathrm{b}$ \\
\hline Adult male & 61 & 13 & 45 & 11 & 60 & 17 \\
\hline Subadult males & 7 & 4 & 17 & 6 & 7 & 10 \\
\hline Adult females & 124 & 92 & 74 & 103 & 65 & 105 \\
\hline Subadult females & 15 & 45 & 25 & 68 & 15 & 48 \\
\hline
\end{tabular}

significantly greater than expected in the watered population $(p<0.005$; $\chi^{2}$-test). By contrast, the control population had significantly fewer breeding females than expected $\left(p<0.05 ; \chi^{2}\right.$-test). Population $B$ had the expected number of breeding females $\left(p>0.10 ; \chi^{2}\right.$-test).

Table 3

Autopsy data for females. Because of small sample size and the wide range of body weights, data are presented for each individual.

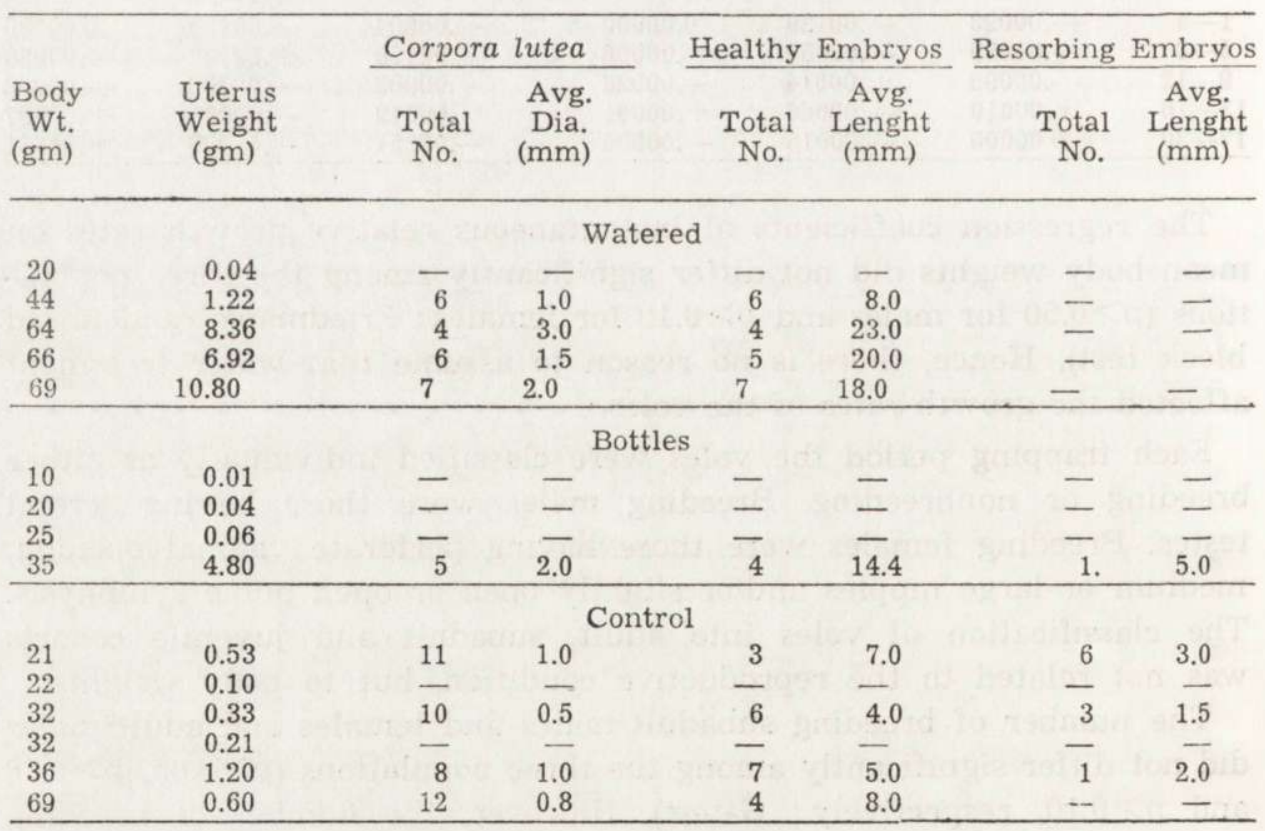


Autopsy data (Tables 3,4 ) were used to calculate ratios of : (a) testes weight/body weight, (b) uterus weight/body weight, and (c) number of healthy embryos/number of corpora lutea.

Testes weight/body weight and uterus weight/body weight ratios were not significantly different among the three populations $(p>0.10$; KruskalWallis test). However, uterus weight/body weight ratio of pregnant females was significantly higher in the watered population than in the control population ( $p=0.05$; Wilcoxon's two-sample test). The difference can be due to differences in age and/or stage of pregnancy.

\section{Table 4}

Autopsy data fore males. Because of small sample size and range of body size, data are presented for each individual. $\mathrm{S}=$ scrotal; $\mathrm{A}=$ abdominal.

\begin{tabular}{lccc}
\hline & Body Weight $(\mathrm{gm})$ & Testes Position & Testes Weight $(\mathrm{gm})$ \\
\hline \multirow{2}{*}{ Watered } & 47 & $\mathrm{~S}$ & 1.59 \\
& 51 & $\mathrm{~S}$ & 1.69 \\
\hline \multirow{3}{*}{ Bottles } & 31 & $\mathrm{~A}$ & 1.00 \\
& 44 & $\mathrm{~A}$ & 1.37 \\
& 52 & $\mathrm{~S}$ & 1.65 \\
\hline & 45 & $\mathrm{~A}$ & 0.88 \\
Control & 48 & $\mathrm{~S}$ & 1.53 \\
& 50 & $\mathrm{~S}$ & 1.54 \\
& 36 & $\mathrm{~S}$ & 2.33 \\
\hline
\end{tabular}

The total number of embryos constituted $67 \%$ of the total number of corpora lutea (Table 3). Eleven embryos were resorbing; ten were from the control population. The watered population had a significantly higher ratio of healthy embryos/corpora lutea than the control population $(p=0.05$; Wilcoxon's two-sample test). However, all females in the control population were at earlier stages of pregnancy compared to those of the watered population (Table 3); consequently, the control population might have lost more embryos if the females had reached the same stages of pregnancy as those of the watered population. Hence, one may argue that the test was conservative.

The number of pregnant females that lost embryos differed significantly among the three populations $(p<0.25 ; G$-test). Goodness of fit multiple comparison revealed that population $W$ lost significantly fewer embryos than expected ( $p<0.025 ; \chi^{2}$-test), population $C$ lost significantly more embryos than expected $\left(p<0.005 ; \chi^{2}\right.$-test) and population $B$ had the expected number of embryos ( $p>0.50 ; \chi^{2}$-test).

Predators encountered in the study area were removed immediately. These included a bull snake (Pituophis melanoleucus) and two copperheads (Agkistrodon contortrix) from enclosure $B$, two copperheads from 
enclosure $W$, and one copperhead from the control enclosure. Two feral cats were seen in the watered enclosure. Cats can destroy voles in the traps. No avian predators were observed.

\section{DISCUSSION}

\section{Effect of Watering}

Watering did not prevent population decline. Because the decline occurred in all three populations, a common cause seems likely. Predation cannot be eliminated as a possible cause of the population decline. However, the finding of different numbers of predators among the three enclosures and the removal of all predators reduce the likelihood that predation was the cause. The decline could have resulted from the introduced laboratory animals being too inbred to survive field conditions. However, the decline of the control population, despite the large number of wild immigrants, suggests that inbreeding in laboratory animals unlikely caused the decline.

Birney et al. (1976) emphasized the importance of cover in relation to predation rates, conspecific encounters, microhabitat condition, and availability of food. They concluded that there is a threshold amount of cover for a breeding Microtus population and another threshold for a cycling population. Grant et al. (1977) attributed the changes in small mammal communities to changes in vegetation structure. In this study, even though the vegetation structure was apparently the same and the control enclosure maintained more cover and received the same amount of water for more than half the study period (Abdellatif, 1980), the watered population supported significantly heavier voles and more breeding females. At the same time, population $B$ did not differ from the control in the demographic parameters studied. These results suggest that provision of water per se was not sufficient to restore normal reproductive activity and population growth of Microtus. A similar conclusion was reached by Christian (1979) for desert rodents.

Possibly reproduction is triggered chemically in $M$. ochrogaster as it is in M. montanus (Negus \& Berger, 1977). Brome is a cool weather grass ; the amount of water may have been inadequate to initiate sufficient new growth until early fall when temperatures were cooler. Possibly the voles were stressed by the high summer temperatures and could not maintain a metabolic balance permitting reproduction. Only further physiological and ecological studies can clarify these issues.

Interpretation of the autopsy data is difficult because of small sample size. However, the results were consistent with those of the demographic 
data; breeding females differed significantly in response to drought whereas males did not. The resorption of most embryos in the control population indicated a severe physiological stress. The significantly greater loss of embryos and absence of females at late stages of pregnancy in the control population relative to the watered population indicate that watering released the stress in the latter.

\section{Watering Effect : A Graphical Model}

Both food quality (Cole \& Batzli, 1979) and microhabitat conditions (Grant et al., 1979) affect population growth of $M$. ochrogaster. The model presented here (Fig. 3) predicts that watering leads to a sequence of effects, analogous to the effects of rainfall, as follows : (a) Modification of the microhabitat affecting the temperature, relative humidity, soil moisture, and microtopography. Hence, it reduces the metabolic costs of maintenance.

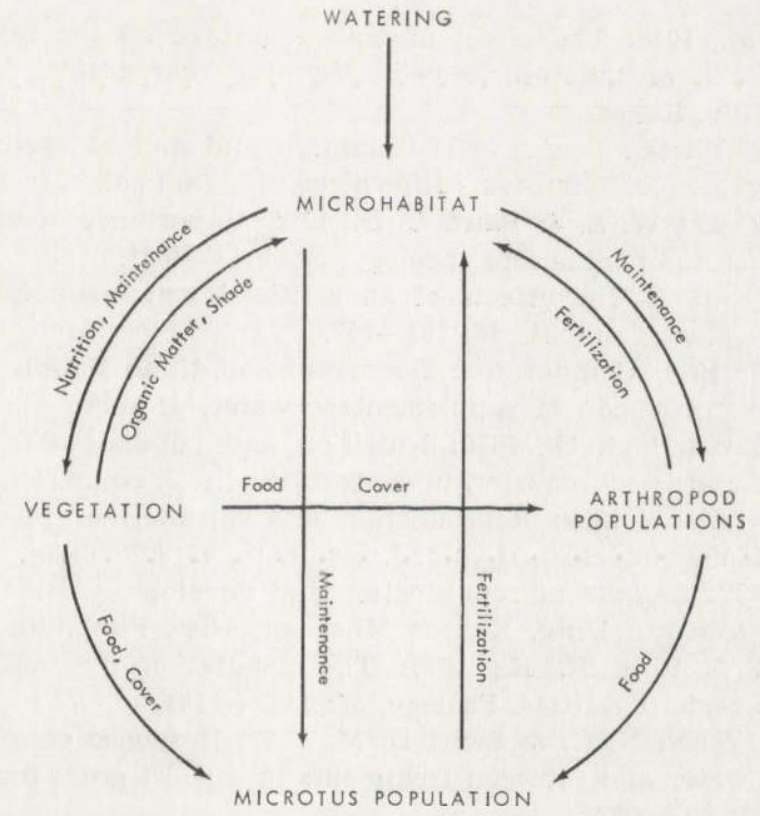

Fig. 3. A graphical model of the effect of watering on a Microtus population.

(b) Improvement of vegetative cover leading to the availability of more and better food for animals.

(c) As a result of the above changes, arthropod populations build up, providing an alternative source of protein for the voles (Cole \& Batzli, 1979). 
(d) The availability of more adequate nutrition and better cover and the improvement of the physical conditions improve the reproductive activity and population growth of $M$. ochrogaster.

The results of this study were consistent with the presented model; specifically, the watered population was superior over either of the other populations in maintaining greater breeding activity and heavier body weights. However, the replication of this experiment and monitoring the amount and quality of cover, arthropod biomass, and microhabitat conditions, are necessary for testing the predictions of this model.

Acknowledgements: We thank Dr. Norman A. Slade for assistance with the statistical analysis and Dr. Robert A. Hoffmann for aid with the autopsy procedure. We appreciate the various contributions of W. Dean Kettle, Bruce McGillivray, Kelly Johnson, Susan Katz, Juli Armstrong and Nick Laila. Computer facilities were provided by the University of Kansas Computation Center. The senior author gratefully thanks AFGRAD for his support.

\section{REFERENCES}

1. Abdellatif E. M., 1980: The effect of water-shortage on the reproduction and population growth of the prairie vole, Microtus ochrogaster, during summer. M.A. Thesis, Univ. Kansas.

2. Batzli G. O. \& Pitelka F. A., 1971: Condition and diet of cycling populations of the California vole, Microtus californicus. J. Mammal., 52: 141-163.

3. Birney E. C., Grant W. E. \& Baird D. D., 1976: Importance of vegetative cover to cycles of Microtus populations. Ecology, 57: 1043-1051.

4. Bradford D. F., 1975: The effects of an artificial water supply on free-living Peromyscus truei. J. Mammal., 56: 705-707.

5. Christian D. P., 1979: Comparative demography of three Namib desert rodents: responses to the provision of supplementary water. J. Mammal., 60: 679—690.

6. Cole F. R. \& Batzli G. O., 1979: Nutrition and population dynamics of the prairie vole, Microtus ochrogaster, in central Illinois. J. Anim. Ecol., 48: 455-470.

7. Corthrum K. W. Jr., 1967: Reproduction and duration of placental scars in the prairie vole and the eastern vole. J. Mammal., 48: 287-292.

8. Fitch H. S., 1957: Aspects of reproduction and development in the prairie vole (Microtus ochrogaster). Univ. Kansas Mus. nat. Hist. Publ., 10: 129-161.

9. Gaines M. S. \& Rose R. K., 1976: The population dynamics of Microtus ochrogaster in eastern Kansas. Ecology, 57: 1145-1161.

10. Grant W. E., French N. R. \& Swift D. M., 1977: Response of a small mammal community to water and nitrogen treatments in a short grass prairie ecosystem. J. Mammal., 58: 637-652.

11. Hamilton W. J., Jr., 1941: Reproduction of the field mouse, Microtus pensylvanicus (Ord.). Cornell Univ. Agric. Exp. Stn. Mem., 237: 1-23.

12. Hollander M. \& Wolfe D. A., 1973: Nonparametric statistical methods. John Wiley \& Sons: $1-503$. New York.

13. Jameson E. W., Jr., 1947: Natural history of the prairie vole. Univ. Kansas Mus. nat. Hist. Publ., 1 : 125-151.

14. Krebs C. J., 1967: Computer programs for analysis of demographic data from small mammal populations. Indiana Univ, Mimeo. 
15. Martin E. P., 1956: A population study of the prairie vole (Microtus ochrogaster) in Northeastern Kansas. Univ. Kansas Mus. nat. Hist. Publ., 8: 361-416.

16. Negus N. C. \& Berger P. J., 1977: Experimental triggering of reproduction in in a natural population of Microtus montanus. Science, 196: 1230-1231.

17. Newsome A. E., Stendell R. C. \& Myers J. H., 1976: Free-watering a wild population of house mice: a test of an Australian hypothesis in California. J. Mammal., 57: 677-686.

18. Rose R. K. \& Gaines M. S., 1978: The reproductive cycle of Microtus ochrogaster in eastern Kansas. Ecol. Monogr., 48: 21-42.

19. Sokal R. R. \& Rohlf F. J., 1969: Biometry. W. H. Freeman and Company: 1-776. San Francisco.

20. Stearns S., 1976: Life history tactics: a review of ideas. Q. Rev. Biol., 51: 3-25. Accepted, December 20, 1981.

Eisa M. ABDELLATIF, Kenneth B. ARMitAGE, Michael S. GAINES i Michael L. JOHNSON

WPEYW NAWADNIANIA NA POPULACJE MICROTUS OCHROGASTER

\section{Streszczenie}

Wyjściową hipotezą pracy było, że brak wody per se lub wody jako stymulatora wzrostu roślinności jest powodem spadku rozrodu w populacji $M$. ochrogaster w ciągu lata. Badania prowadzono od 21 maja do 16 października 1979 r., na trzech ogrodzonych powierzchniach, po 0,81 ha każda. Jedna z nich była nawadniana przez 8 deszczowni, druga zaopatrywana w wodę $z$ flaszek, w taki sposób aby nie zraszała roślin, a trzecia stanowiła kontrolę. Złowiono w żywołówki około 200 norników. Począwszy od ostatniego dnia września, złowione zwierzęta usuwano z powierzchni i badano ich fizjologiczny stan wywolany suszą we wrześniu (Ryc. 1). $\mathrm{Na}$ nawadnianej powierzchni norniki były istotnie cięższe a udział samic w rozrodzie statystycznie istotnie wyższy niż w pozostałych populacjach. Kontrolna populacja wykazała istotnie niższą liczbę embrionów niż populacja z powierzchni nawadnianej. W zagrodzie na której zwierzęta mogły pić z flaszek norniki nie różniły się od zwierząt $\mathrm{z}$ powierzchni kontrolnej (Tabela 1, 2, 3, 4 i Ryc. 2).

Wyniki tej pracy wskazują, że obniżanie się rozrodu latem niewątpliwie zależy od stanu wegetacyjnego roślin, stymulowanego ilością wody. Przedstawiono graficzny model ilustrujący przybliżony wpływ nawadniania (Ryc. 3). 